\title{
DISTRIBUTION AND ABUNDANCE OF CHIRONOMIDAE (DIPTERA, INSECTA) IN AN IMPACTED WATERSHED IN SOUTH-EAST BRAZIL
}

\author{
MARQUES, M. M. G. S. M., BARBOSA, F. A. R. and CALLISTO, M. \\ Laboratório de Limnologia, Departamento de Biologia Geral, ICB/UFMG, C.P. 486, \\ CEP 30161-970, Belo Horizonte, MG, Brazil \\ Correspondence to: Francisco Antônio R. Barbosa, Laboratório de Limnologia, Departamento de Biologia \\ Geral, ICB/UFMG, C.P. 486, CEP 30161-970, Belo Horizonte, MG, Brazil, e-mail: barbosa@mono.icb.ufmg.br \\ Received July 14, 1998 - Accepted November 29, 1998 - Distributed December 22, 1999
}

(With 3 figures)

\begin{abstract}
Patterns of abundance and distribution of chironomid midges (Diptera, Chironomidae) in the middle Rio Doce basin were analysed. Human activities (mining, steel processing, and Eucalyptus spp. forestry) contribute to environmental degradation and low water quality in this watershed. Physical and chemical water traits (dissolved oxygen, $\mathrm{pH}$, total alkalinity, electric conductivity, phosphorus and nitrogen concentrations) of 20 sampling points were used in a Principal Component Analysis (PCA) to establish the best and worst water quality. Sampling points recorded as the most polluted showed low genus richness of Chironomidae, less than five genera from the total 23, and dominance of the genus Chironomus, a bioindicator of environmental stress. Following Chironomus, the second most frequent and abundant genus was Cricotopus, whose distribution could not be related to pollution levels. The Tanypodinae sub-family showed certain sensitivity to low dissolved oxygen concentrations and high nutrients levels, and was not found at points of high pollution levels.
\end{abstract}

Key words: Chironomus, bioindicators, pollution.

\section{RESUMO}

\section{Distribuição e abundância de Chironomidae (Diptera, Insecta) em uma bacia hidrográfica impactada no Sudeste do Brasil}

Foram investigados os padrões de distribuição e abundância de larvas da família Chironomidae (Diptera, Insecta) ao longo do trecho médio da bacia do Rio Doce, onde as atividades de mineração, garimpo, siderurgia e monocultura de Eucalyptus spp. contribuem para a degradação ambiental e baixa qualidade de água. Utilizando-se as variáveis físicas e químicas (oxigênio dissolvido, $\mathrm{pH}$, alcalinidade total, condutividade elétrica e as concentrações de nitrogênio e fósforo totais) de cada uma das 20 estações de amostragem, foi possível distinguir aquelas de pior e melhor qualidade de água, através da Análise de Componentes Principais (PCA). As estações apontadas como de pior qualidade apresentaram baixa riqueza de Chironomidae, menos de cinco gêneros de um total de 23 , e dominância do gênero Chironomus, indicador de "stress" ambiental. Depois de Chironomus, o segundo gênero mais freqüente e abundante encontrado nessa bacia foi Cricotopus, cuja distribuição, no entanto, não foi atribuída à poluição. A subfamília Tanypodinae mostrou uma certa sensibilidade aos baixos teores de oxigênio dissolvido e altas concentrações de nutrientes, não sendo encontrada naquelas estações mais poluídas.

Palavras-chave: Chironomus, bioindicadores, poluição. 


\section{INTRODUCTION}

The family Chironomidae is an important freshwater macroinvertebrate group due to its great abundance, high diversity, and presence in a majority of continental aquatic ecosystems (Epler, 1992). As detritivores chironomid larvae are essential to the circulation of nutrients in lakes and reservoirs and may in fact change the speed of the eutrophication process in the course of their feeding (Dévai, 1990). Furthermore, their quick generation turnover and rapid growth rate guarantee an availability of biomass to aquatic ecosystem dynamics (Menzie, 1981).

According to the "river continuum concept" (Vannote et al., 1980), in which functional groups distributed throughout a river are classified according to feeding habits, the Chironomidae family, excepting the predator species, should be best represented in quantitative terms in rivers of larger orders of magnitude. Chironomids tend to dominate, along with Oligochaeta and Hirudinea, in areas where there are influxes from organic sewers and low levels of oxygen (Fagundes \& Shimizu, 1997). Here these groups can reach excessive densities, as observed by these authors in Sorocaba river, São Paulo State, and by Barbosa et al. (1997) in the middle Rio Doce basin.

Chironomidae has been used as indicadors of water quality since the beginning of the century after the introduction of the Saprobic System (Kolkwitz \& Marsson, 1908, 1909, apud Chutter, 1972). Several biological indices concerning evaluation and monitoring of water quality rely heavily on them (Plafkin et al., 1990; Barbosa et al., 1995, 1997). Changes in species composition, dominance of pollution tolerant species, and frequency of occurrance of deformities on larval head capsules, are some of the commonly used features in these types of evaluations (Johnson et al., 1993).

Although known to be important, knowledge on Chironomidae fauna in lotic ecosystems is still scarce in Brazil, since studies related to the benthic fauna in general and to Chironomidae in particular are, for the most part, restricted to lentic systems such as lagoons, lakes, dams, and reservoirs (Nessimian, 1995).

The present study intended to examine the distribution and abundance of Chironomidae larvae along the Piracicaba River, correlating this data with human impacts and water quality.

\section{THESTUDY AREA}

The Piracicaba river is situated in the eastern region of Minas Gerais State, Brazil, enclosing a $5,896 \mathrm{~km}^{2}$ area and 22 municipalities. Approximately 700,000 people live in this region whose economy is based on three major activities: mining, reforestation (Eucalyptus spp.), and steel processing (Guerra, 1992). These activities along with an accelerating urbanization process are contributing to the increasing degradation of water bodies and their associated resources.

The predominant climate has two defined seasons: dry, from April until September, and rainy, from October until March. The topography is highly mountainous, thus faciliting erosive processes, also affecting the aquatic ecosystems in the area (Guerra, 1992).

In this area 20 sampling stations along the river were chosen (Fig. 1) in order to evaluate the major human impacts. A detailed description of these sampling areas including the predominant human activities and impacts is presented in Barbosa et al. (1997a).

\section{MATERIAL AND METHODS}

Collections were carried out at three dry and two wet seasons during the period July/1993August/1995. The three first periods of collection (Jul/93, Dec/93, and Jul/94) included 15 sampling stations, while for the next two periods (Feb/95 and Aug/95) five more sampling stations were added. The last five sampling stations $(16,17,18$, 19, and 20) do not follow the spatial ordination down the basin, but they correspond to the sampling stations 6A, 7A, 9A, 10A, and 11C as described in Barbosa et al. (1997b).

Physical and chemical characterization of each sampling station was carried out by analyzing water samples collected from the subsurface and sediment collected from one of the margins. Concentration of dissolved oxygen (Winkler method), $\mathrm{pH}$, temperature, electric conductivity, total alkalinity, total nitrogen and total phosphorus (according to Mackereth et al. (1978)), and the percentage of organic matter in the sediment (following Jackson (1974)) were determined and used in this characterization.

Benthic organisms were sampled with metallic nets (mesh $<1 \mathrm{~mm}$ ) and an Ekman-Birge 
dredge at the same points and periods and fixed in $5 \%$ formalin. At the laboratory samples were washed and sorted out and the collected organisms fixed in $70 \%$ alcohol and deposited in the collection of benthic aquatic macroinvertebrates of the Institute of Biological Sciences, Federal University of Minas Gerais. The larvae of Chironomidae were identified at the genera level through the taxonomic keys of Oliver et al. (1978), Simpson \& Bode (1980), Wiederholm (1983), Epler (1995), TrivinhoStrixino \& Strixino (1995) and Cranston (1996). The results are expressed in terms of relative abundance $(\%)$ of each genus.

The values of physical and chemical analysis were used to ordinate the sampling stations and the periods of collection through the Principal Components Analysis (PCA) under a correlation matrix. The two defined main axes of this analysis were then used in a Canonical Correlation Analysis (CCA) together with data of abundance of the main sub-families of Chironomidae.

The numerical abundance of the sub-families was log-transformed for the accomplishment of this analysis.

\section{RESULTS}

Physical and chemical variables (Table 1) indicate enrichment with nutrients, mainly nitrogen, in sampling stations 9,10, 11 and 19, suggesting an advanced degree of eutrophication in these stretches. Station 11 showed the highest recorded phosphorus concentrations, as well as the lowest oxygen levels.

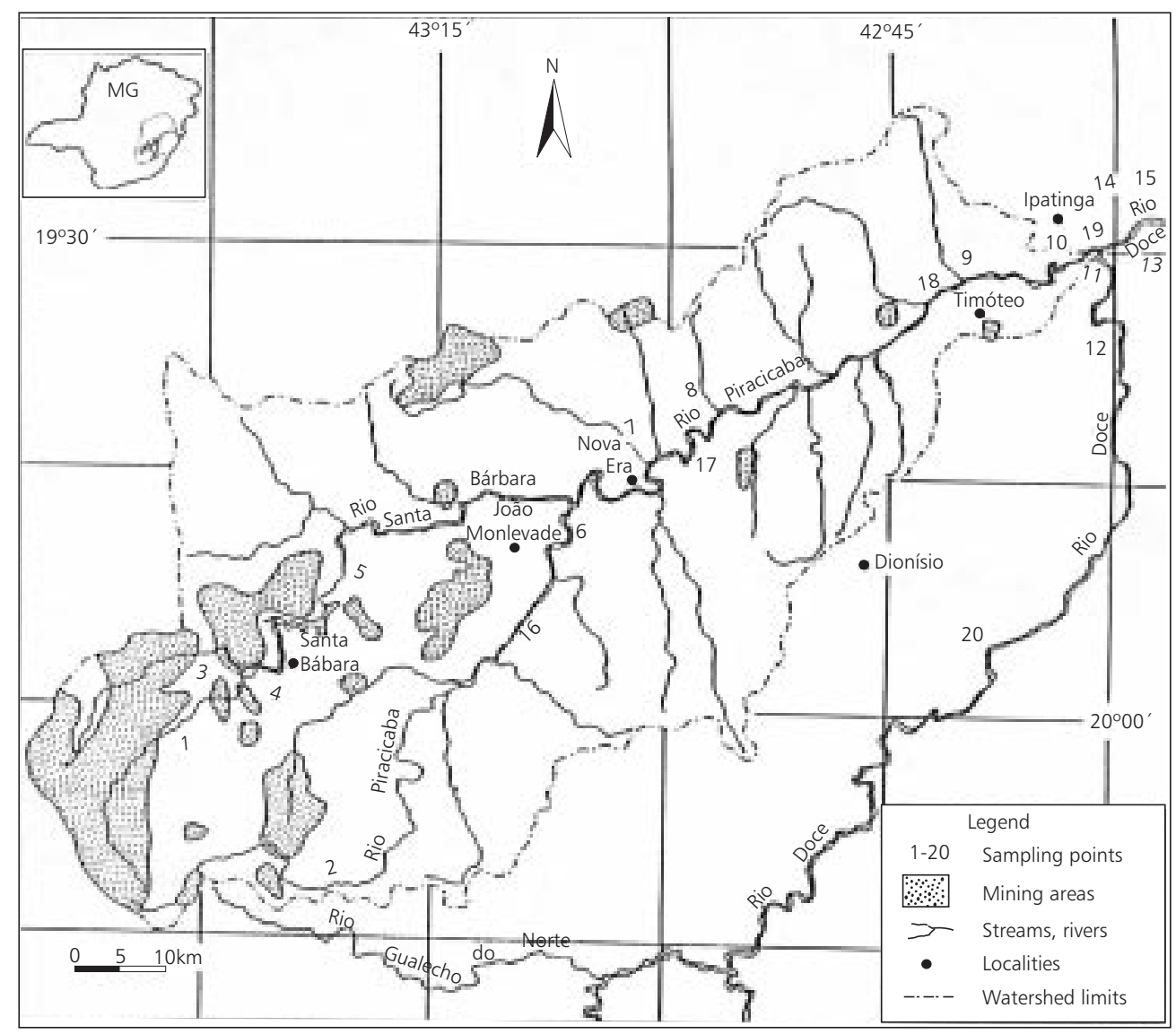

Fig. 1 - Map of the study area and sampling stations in the Rio Piracicaba basin. 
TABLE 1

Physical and chemical traits in Rio Piracicaba basin sampling points. Average values for the five collecting seasons (1993/1995).

\begin{tabular}{|c|c|c|c|c|c|c|c|c|}
\hline Point & $\begin{array}{c}\text { Temper } \\
\left({ }^{\mathbf{C}} \mathbf{C}\right)\end{array}$ & $\begin{array}{c}\mathbf{D O} \\
(\mathbf{m g} / \mathbf{l})\end{array}$ & $\mathbf{p H}$ & $\begin{array}{c}\text { Conduct. } \\
(\mu \mathbf{S} / \mathbf{c m})\end{array}$ & $\begin{array}{c}\text { Alkalinity } \\
\left(\mathbf{m e q} \mathbf{C O}_{2} / \mathbf{l}\right)\end{array}$ & $\begin{array}{c}\text { N-total } \\
\mu \mathbf{g} / \mathbf{l}\end{array}$ & $\begin{array}{c}\text { P-total } \\
\mu \mathbf{g} / \mathbf{l}\end{array}$ & $\begin{array}{c}\text { OMS } \\
\mathbf{\%}\end{array}$ \\
\hline 1 & 17.3 & 9.9 & 3.8 & 17.2 & 0 & 262.4 & 30.3 & 0.2 \\
\hline 2 & 20.9 & 8.8 & 7.1 & 59.6 & 0.4 & 420.6 & 72.0 & 3.5 \\
\hline 3 & 20.1 & 6.6 & 8.6 & 121.6 & 1.0 & 1889 & 89.1 & 9.3 \\
\hline 4 & 20.2 & 7.2 & 6.7 & 64.6 & 0.4 & 718.5 & 116.5 & 5.6 \\
\hline 5 & 21.2 & 8.5 & 6.9 & 52.9 & 0.4 & 471.3 & 45.8 & 1.9 \\
\hline 6 & 23.0 & 8.4 & 7.2 & 46.2 & 0.5 & 1219.3 & 146.5 & 5.5 \\
\hline 7 & 20.0 & 9.2 & 7.0 & 45.5 & 0.3 & 1587 & 251.8 & 10.4 \\
\hline 8 & 20.4 & 9.3 & 7.2 & 20.8 & 0.2 & 482.6 & 99.7 & 5.2 \\
\hline 9 & 24.0 & 8.4 & 6.9 & 68.48 & 0.5 & 2132 & 103.9 & 6.2 \\
\hline 10 & 25.9 & 7.7 & 6.9 & 115.6 & 0.4 & 3112 & 230.6 & 6.2 \\
\hline 11 & 27.6 & 4.3 & 6.9 & 186.9 & 1.2 & 5257 & 400.5 & 5.8 \\
\hline 12 & 25.1 & 9.6 & 7.1 & 43.84 & 0.5 & 454.3 & 101.7 & 6.6 \\
\hline 13 & 24.3 & 8.3 & 6.9 & 54.0 & 0.2 & 1221 & 115.9 & NA \\
\hline 14 & 25.0 & 8.2 & 6.9 & 120.3 & 0.5 & 837.8 & 128.7 & 4.9 \\
\hline 15 & 25.1 & 9.1 & 7.2 & 70.52 & 0.4 & 538.9 & 166.6 & 7.2 \\
\hline 16 & 22.1 & 9.5 & 6.4 & 24.1 & 0.2 & 136.2 & 32.8 & - \\
\hline 17 & 23.3 & 24.4 & 6.7 & 45.5 & 0.3 & 574.5 & 69.4 & - \\
\hline 18 & 25.3 & 8.8 & 6.5 & 42.1 & 0.3 & 775.6 & 60.2 & - \\
\hline 19 & 27.0 & 1.3 & 6.8 & 119.6 & 1.6 & 7283 & 612.4 & - \\
\hline 20 & 25.2 & 9.2 & 7.2 & 42.9 & 0.3 & 308.8 & 52.3 & - \\
\hline
\end{tabular}

OMS = organic matter at sediment, $\mathrm{DO}=$ dissolved oxygen

On the other hand, the percentage of organic matter in the sediment was extremely low in station 1, exhibiting the highest values in stations 3 and 7.

The first two determined axes from PCA explain $c a .68 \%$ of the total data variation, and the first axis shows a strong positive correlation with total nitrogen, alkalinity, conductivity, and total phosphorus, and negative correlation with dissolved oxygen, thus indicating a direct pollution gradient, shown in Table 2. The second axis from the PCA only showed a strong negative correlation, with $\mathrm{pH}$.

The graphical expression of this analysis (Fig. 2), suggests stations 1 and 3 as unique stations throughout the seasons, the last one, except in July of 1994, when it was in similar conditions to the remaining stations. Stations 10,11 , and 19 , are also grouped in levels of higher pollution, though they do not form distinct groups. None of the re- maining stations presented isolately physical or chemical features allowing their distinction, nor did they present marked differences between dry and rainy seasons.

A total of 23 genera of Chironomidae were identified from the sampling stations, a rather low figure due to the difficulties of identification of pupae and some particular groups (e.g. tribe Tanytarsini). The most frequent genera were: Chironomus and Cricotopus (88\%), Polypedilum (82\%), Ablabesmyia (76\%), Parachironomus (65\%), and Cryptochironomus (59\%). Besides being most frequent, Chironomus and Cricotopus were also the most numerically abundant (Table 3 ).

The chironomid richness at each sampling station is shown in Fig. 3. Stations 4 and 5 exhibited the highest richness (17 and 15 genera respectively), while stations $17,18,19$ and 20 , showed the lowest values. 
TABLE 2

Correlation of PCA axis and abiotic measures at Rio Piracicaba basin (1993/1995).

\begin{tabular}{|l|c|c|}
\hline Abiotic measures & Axis 1 & Axis 2 \\
\hline DO & -0.590 & -0.210 \\
\hline Alkalinity & 0.843 & -0.207 \\
\hline Conductivity & 0.815 & -0.141 \\
\hline $\mathrm{pH}$ & 0.365 & -0.843 \\
\hline N-total & 0.886 & 0.251 \\
\hline P-total & 0.649 & 0.387 \\
\hline Explained variation & $51 \%$ & $17 \%$ \\
\hline
\end{tabular}

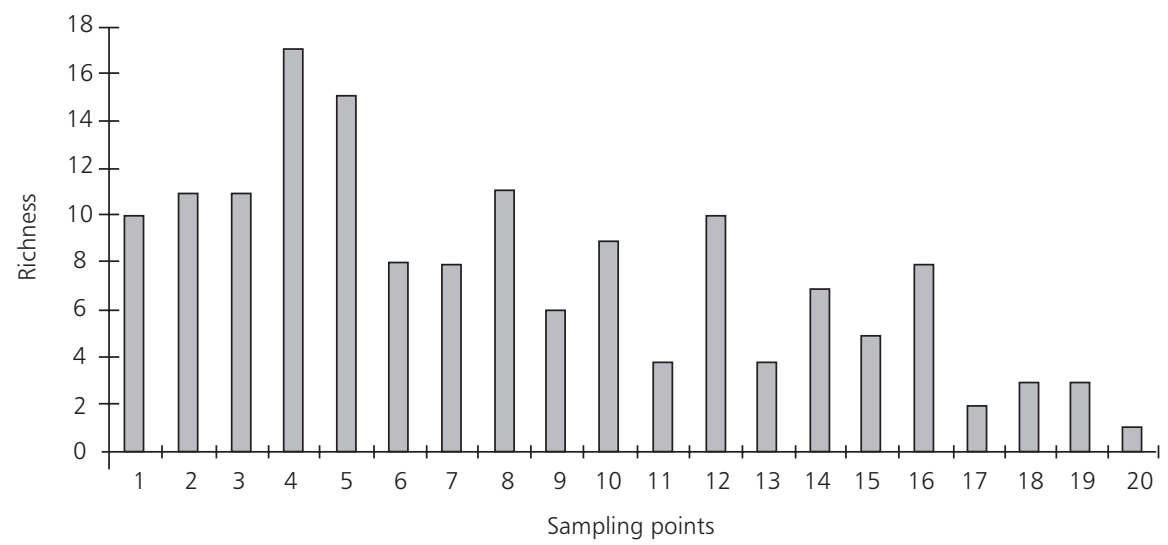

Fig. 2 - Graphical representation of the PCA showing sampling points and collecting periods.

The canonical correlation of Chironomidae sub-families and the extracted axes from PCA are significant only for the first canonic axis $(\mathrm{p}<0.05$, Table 4). The Chironomini tribe, represented mainly by Chironomus genus, and the first axis from the PCA show strong negative correlation with the first canonical axis, indicating, if not affinity for, at least some strong tolerance to eutrophic conditions. On the other hand, other sub-families, mainly Tanypodinae, are negatively associated with axis one thus demonstrating sensitivity to high pollution levels. The community structure did not show significant changes when separated according to dry and rain periods.

\section{DISCUSSION}

The canonic ordinance was successful only when explaining the distribution of the Chironomini tribe. As Chironomus is not only the most frequent but also the most abundant genus of the Chironomini, it had greater weight in the analysis and must be taken into account that it was responsible for such result.

The increase in density of larvae of the Chironomus genus in environments with eutrophic features has been registered in several types of ecosystems (Frank, 1963; Learner \& Edwards, 1966; Devái, 1988; Tate \& Heiny, 1995; Botts, 1997). All the stations with eutrophic features as determined by PCA (3, 10, 11 and 19) have Chironomus present and, with exception of station 10 , this is the dominant genus.

The genus Cricotopus appears as dominant at stations $1,5,7,10$, and 15 , stretches that have different trophic status and impact levels. Its distribution, therefore, cannot be primarily associated with water quality. Menzie (1981) recorded the dominance of Cricotopus sylvestris in Myriophyllum, corresponding to $80 \%$ of all associated 
larvae. Smiths \& Young (1973), studying small ponds in England, also observed that this genus was common living in the vegetation of the margins. Dvorák (1996) found strong positive correlation between the abundance of Cricotopus and the biomass of diatoms on the surface of aquatic macrophytes. Thus, the distribution of this genus is more likely dependent on the presence of food supplies than the physical and chemical traits of the water column.

TABLE 3

Relative abundance of Chironomidae at sampling points in Rio Piracicaba basin, in the period 1993/1995.

\begin{tabular}{|c|c|c|c|c|c|c|c|c|c|c|c|c|c|c|c|c|c|c|c|c|}
\hline & 1 & 2 & 3 & 4 & 5 & 6 & 7 & 8 & 9 & 10 & 11 & 12 & 13 & 14 & 15 & 16 & 17 & 18 & 19 & 20 \\
\hline Ablabesmyia & $*$ & $*$ & $*$ & $*$ & $*$ & - & $*$ & $*$ & $*$ & $*$ & - & $*$ & $*$ & $* *$ & $*$ & $*$ & $* *$ & - & - & $* *$ \\
\hline Alotanypus & - & - & $*$ & - & - & $*$ & - & - & - & - & - & - & - & - & - & - & - & - & - & - \\
\hline Djalmabatista & - & - & - & - & - & - & - & - & - & - & - & - & - & - & - & $*$ & - & - & - & - \\
\hline Fittkauimyia & - & $*$ & - & $*$ & - & - & - & - & - & - & - & - & - & - & - & - & - & - & - & - \\
\hline Labrundinia & - & - & - & $*$ & - & - & - & - & - & - & - & - & - & - & - & - & - & - & - & - \\
\hline Monopelopia & - & $*$ & - & - & - & - & - & - & - & - & - & - & - & - & - & - & - & - & - & - \\
\hline Pentaneura & $*$ & - & - & - & $*$ & - & - & - & - & - & - & - & - & - & - & - & - & - & - & - \\
\hline Tanypus & $*$ & $* *$ & - & $* *$ & $*$ & - & $*$ & $*$ & - & - & - & $* *$ & - & $*$ & - & - & - & - & - & - \\
\hline Tanypodinae NI & $*$ & - & - & $*$ & $*$ & $*$ & $*$ & - & - & - & - & $*$ & $* *$ & - & $*$ & $*$ & - & - & - & - \\
\hline Corynoneura & - & - & - & - & - & - & - & - & - & - & - & - & - & - & - & - & - & - & * & - \\
\hline Cricotopus & $* *$ & $*$ & $* *$ & $*$ & $* *$ & $* *$ & $* *$ & $*$ & $*$ & $* *$ & - & $*$ & $*$ & $*$ & $* *$ & - & - & $*$ & $*$ & - \\
\hline Nanocladius & - & $*$ & $*$ & - & $*$ & $*$ & $*$ & $*$ & - & $*$ & - & - & - & - & - & - & - & - & - & - \\
\hline Thienemanniella & - & - & $*$ & - & - & - & - & - & - & - & - & - & - & - & - & - & - & - & & - \\
\hline Orthocladiinae NI & - & - & - & $*$ & $*$ & $*$ & - & - & - & - & - & - & - & - & - & - & - & - & - & - \\
\hline Asheum & - & - & $*$ & $*$ & - & - & - & - & - & - & - & - & - & - & - & - & - & - & - & - \\
\hline Chironomus & $*$ & - & $* *$ & $*$ & $*$ & $* *$ & $*$ & $*$ & $* *$ & $*$ & $* *$ & - & - & $*$ & - & $*$ & $*$ & $* *$ & $* * *$ & - \\
\hline Cryptochironomus & - & $*$ & $*$ & $*$ & $*$ & - & $*$ & * & $*$ & - & - & $*$ & - & $*$ & - & $*$ & - & - & - & - \\
\hline Endochironomus & - & - & - & - & - & - & - & - & - & $*$ & - & - & - & - & - & - & - & - & - & - \\
\hline Goeldichironomus & $*$ & - & - & - & $*$ & - & - & $*$ & - & $*$ & $*$ & $*$ & - & - & - & - & - & - & - & - \\
\hline Parachironomus & - & $*$ & $*$ & $* *$ & $*$ & - & - & * & $*$ & $*$ & * & $*$ & - & $*$ & - & $*$ & - & - & - & - \\
\hline Paracladopelma & - & - & - & - & - & - & - & - & - & - & - & - & - & $*$ & - & - & - & - & - & - \\
\hline Polypedilum & $*$ & $*$ & $*$ & $*$ & $*$ & $*$ & $*$ & * & $*$ & $*$ & $*$ & $*$ & $*$ & - & $* *$ & $* *$ & - & - & - & - \\
\hline Stenochironomus & - & - & - & $*$ & - & - & - & - & - & - & - & - & - & - & - & - & - & - & - & - \\
\hline Tribelos & $*$ & - & - & $*$ & - & - & - & - & - & $*$ & - & - & - & - & $*$ & - & - & - & - & - \\
\hline Chironomini NI & - & $*$ & $*$ & $*$ & $*$ & $*$ & - & $*$ & - & - & - & $*$ & - & - & - & - & - & $*$ & - & - \\
\hline Tanytarsus & - & - & - & $*$ & $*$ & - & - & $*$ & - & - & - & - & - & - & - & - & - & - & - & - \\
\hline Tanytarsini g.var. & $*$ & $*$ & - & $*$ & $*$ & - & - & - & - & - & - & $*$ & - & - & - & $*$ & - & - & - & - \\
\hline pupas NI & $*$ & $*$ & $*$ & $*$ & $*$ & $*$ & $*$ & $*$ & $*$ & $*$ & $*$ & $*$ & - & - & $*$ & $*$ & - & $*$ & $*$ & - \\
\hline
\end{tabular}

$*$ relative abundance till $25 \%$, ** relative abundance between 26 and $75 \%$, *** relative abundance between $76 \%-100 \%$, NI $=$ not identified. 


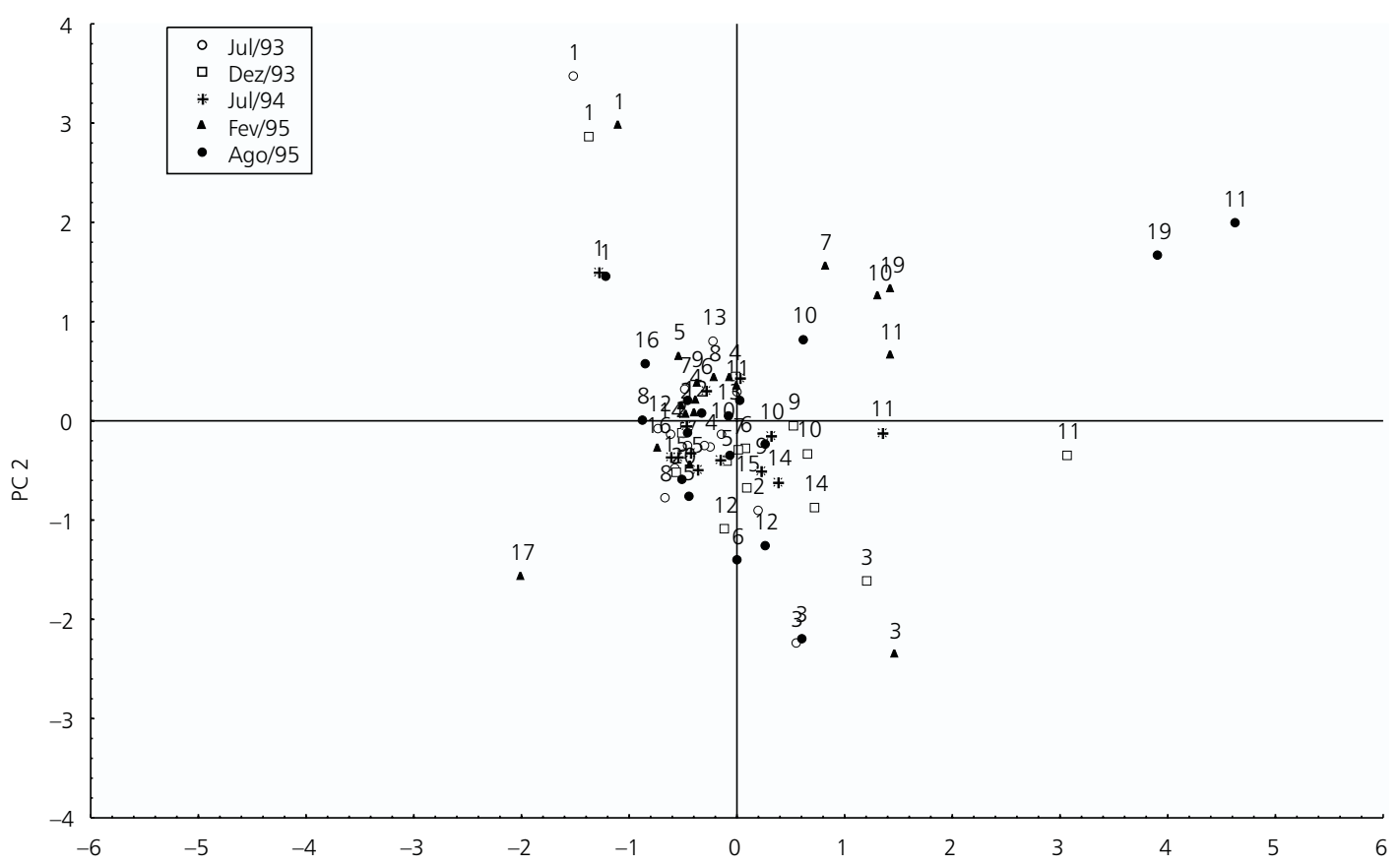

Fig. 3 - Genus richness of Chironomidae at the sampling stations of Piracicaba river during the rainy and dry seasons of 1993/1995.

TABLE 4

Canonical correlation of Chironomidae sub-families abundance and PCA axis 1 and 2.

\begin{tabular}{|l|c|c|}
\hline \multicolumn{1}{|c|}{ Sub-family/tribe } & Canonic axis 1 & Canonic axis 2 \\
\hline Tanypodinae & 0.460 & -0.244 \\
\hline Orthocladiinae & 0.207 & -0.938 \\
\hline Chironomini & -0.724 & -0.444 \\
\hline Tanytarsini & 0.327 & -0.002 \\
\hline PCA axis 1 & -0.999 & -0.015 \\
\hline PCA axis 2 & 0.015 & -0.999 \\
\hline Canonical Correl. Coeficient & 0.42 & 0.13 \\
\hline Chi-square & 17.33 & 1.45 \\
\hline Freedom degrees & 8 & 3 \\
\hline p value & 0.02 & 0.69 \\
\hline
\end{tabular}

Among the sub-families of Chironomidae, Tanypodinae are considered excellent predators. This is known in spite of, as recorded by Nessimian \& Sanseverino (1995), the presence of fragments of vegetation and algae (Desmidiaceae, Cyanophyceae, Diatomaceae and Chlorophyceae) that can be found in its digestive system. Wolfram (1996) states that the main genus of Tanypodinae found in Neusiedler See, Austria, did not have its distribution limited by sediment type or by the concentration of nutrients in the sediment, though a slight preference for small compact sediments was shown. In this case, the horizontal distribution of the organisms inside the lake is attributed to the trophic relationships of the community. In the present work it was not possible to distinguish an 
evident pattern linking the distribution of Tanypodinae to water quality. However, it is interesting to note that the stations characterized as eutrophic by the PCA have a very low richness of Tanypodinae: stations 19 and 11 have no representatives of this sub-family.

All the Chironomidae genera in this study are considered common and tolerant to a wide array of environmental conditions. However, only the Chironomini sub-family, due to bulk presence of Chironomus, showed significant increase in abundance in response to organic enrichment by antropic action and consequent deterioration of water quality.

Such a result demonstrates the necessity of preventing generalizations of taking the whole Chironomidae family as indicator of degraded environments.

The present data allow the conclusion that only the genus Chironomus is a reliable indicator. Future studies on water quality must use the identification at the level of genus in order to assess the "biological status" of a water body.

Acknowledgements - The authors thank M. Sc. Adriano Paglia for helpful advise on the statistical analysis and to Matthew Yoder for reviewing the English text. Financial support was provided by PADCT/ CIAMB project.

\section{REFERENCES}

BARBOSA, F. A. R., MAIA-BARBOSA, P. M., SANTOS, M. B. L., MINGOTI, S. \& AQUINO, V., 1995, Nova ferramenta para o monitoramento da qualidade da água. Ciência Hoje, 19(110): 16-17.

BARBOSA, F. A. R., SOUZA, E. M. M., VIEIRA, F., RENAULT, G. P. C. P., ROCHA, L. A., MAIA-BARBOSA, P. M., OBERDÁ, S. M. \& MINGOTI, S. A., 1997a, Impactos antrópicos e biodiversidade aquática. In: UFMG/ CEDEPLAR-ECMVS, Biodiversidade, População e Economia, 672p.

BARBOSA, F. A. R., PAULA, J. A. \& MONTE-MÓR, R. L. M., 1997b, A bacia hidrográfica como unidade de análise e realidade de integração disciplinar. In: Biodiversidade, População e Economia. UFMG/CEDEPLAR-ECMVS, $672 \mathrm{p}$.

BOTTS, P. S., 1997, Spatial pattern, patch dynamics and successional change: chironomid assemblages in a Lake Erie coastal wetland. Fresh. Biol., 37: 277-286.

CHUTTER, F. M., 1972, An empirical biotic index of the quality of water in South African streams and rivers. Water Research, 6: 19-30.

CRANSTON, P., 1996, Identification guide to the Chironomidae of New South Wales. Australian Water Technologies, 376p.
DÉVAI, G., 1988, Emergence patterns of chironomids in Kesztnely-basin of Lake Balaton (Hungary). Spixiana Suppl., 14: 201-211.

DÉVAI, G., 1990, Ecological background and importance of the change of chironomid fauna in shallow Lake Balaton. Hydrobiol., 191: 189-198.

DVORÁK, J., 1996, An example of relationships between macrophytes, macroinvertebrates and their food resources in a shallow eutrophic lake. Hydrobiol., 339: 27-36.

EPLER, J. H., 1992, Identification manual for the larval Chironomidae (Diptera) of Florida. Florida Department of Environmental Protection, 427p.

EPLER, J. H., 1995, Identification manual for the larval Chironomidae (Diptera) of Florida. Florida Department of Environmental Protection, 315p.

FAGUNDES, R. C. \& SHIMIZU, G. Y., 1997, Avaliação da qualidade da água do Rio Sorocaba-SP, através da comunidade bentônica. Rev. Brasil. Ecol., 1: 63-66.

FRANK, C., 1963, Ecology, production and anaerobic metabolism of Chironomus plumosus L. larvae in a shallow lake. II Anaerobic metabolism. Arch. Hydrobiol., 96 (3): 354-362.

GUERRA, C., 1992, Impactos ambientais na bacia do rio Piracicaba. Monografia de Conclusão de Curso de Especialização. Instituto de Engenharia Ambiental, Delft, Holanda, 77p.

JACKSON, M. L., 1974, Análisis químico de suelos. Ediciones Omega S.A., Barcelona, 662p.

JOHNSON, R. K., WIEDERHOLM, T. \& ROSENBERG, D. M., 1993, Freshwater biomonitoring using individual organisms, populations and species assemblages of benthic macroinvertebrates. In: D. M. Rosenberg \& V. H. Resh (eds.), Freshwater biomonitoring and benthic macroinvertebrates, Chapman Hall, 488p.

LEARNER, M. A. \& EDWARDS, R. W., 1966, The distribution of the midge Chironomus riparius in a polluted river system and its environs. Air \& Wat. Pollut. Int. J., 10: 757-768.

MACKERETH, F. J. K., HERON, J. \& TALlinG, J. F., 1978, Water analysis: some revised methods for limnologists. Freshwater Biological Association, Windermere, 120p.

MENZIE, C. A., 1981, Production ecology of Cricotopus sylvestris (Fabricius) (Diptera: Chironomidae) in a shallow estuarine cove. Limnol. Oceanogr., 26(3): 467-481.

NESSIMIAN, J. L., 1995, Composição da fauna de invertebrados bentônicos em um brejo entre dunas no litoral do Estado do Rio de Janeiro, Brasil. Acta Limnol. Brasil., 7: 41-59.

NESSIMIAN, J. L. \& SANSEVERINO, A. M., 1995, Structure and dynamics of chironomid fauna from a sand dune marsh in Rio de Janeiro State, Brazil. Studies on Neotrop. Fauna and Environ., 30: 207-219.

OLIVER, D. R., McCLYMONT, D. \& ROUSSEL, M. E., 1978, A key to some larvae of Chironomidae (Diptera) from the Mackenzie and Porcupine River watersheds. Fisheries \& Marine Service Technical Report, 791, 73p. 
PLAFKIN, J. L., BARBOUR, M. T., PORTER, K. D., GROSS, S. K. \& HUGHES, R. M., 1990, Rapid bioassessment protocols: for use in streams and rivers. USA/ EPA. Washington D.C., 126p.

SIMPSON, K. W. \& BODE, R. W., 1980, Common larvae of Chironomidae (Diptera) from New York State streams and rivers. New York State Education Department, 105p.

SMITH, V. G. F. \& YOUNG, J. O., 1973, The life histories of some Chironomidae (Diptera) in two ponds on Merseyside, England. Arch. Hydrobiol., 72(3): 333-355.

TATE, C. M. \& HEINY, S. J., 1995, The ordination of benthic invertebrate communities in the South Platte Basin in relation to environmental factors. Fresh. Biol., 33: 439-454.
TRIVINHO-STRIXINO， S. \& STRIXINO, G., 1995, Larvas de Chironomidae (Diptera) do Estado de São Paulo: guia de identificação e diagnose dos gêneros. PPG-ERN/UFSCAR, São Carlos, 229p.

VANNOTE, R. L., MinShall, G. W., CUMMins, K. W., SEDELL, J. R. \& CUSHING, C. E., 1980, The river continuum concept, Can. J. Fish. Aquat. Sci., 37: $130-137$.

WIEDERHOLM, T., 1983, Chironomidae of the Holartic region: keys and diagnoses. Part 1. Larvae. Entomol. Scandin. Suppl., 19: 1-457.

WOLFRAM, G., 1996, Distribution and production of chironomids (Diptera: Chironomidae) in a shallow, alkaline lake (Neusiedler See, Austria). Hydrobiol., 318: 103-115. 